\title{
Високоінтенсивне тренування як засіб фізичної терапії при лівопівкульних геморагічних інсультах: огляд зарубіжного досвіду
}

\author{
УДК 615.825+796.015.15+615.831-005.1
}

\section{М. М. Віноградов, О. Б. Лазарєва}

Національний університет фізичного виховання і спорту України, Київ, Україна

\begin{abstract}
Резюме. Інсульт є найважливішою проблемою охорони здоров'я в багатьох країнах світу. В Україні реєструється понад 111 тис. нових випадків інсульту, які є основною причиною смертності та інвалідизації населення. Мета. Вивчення зарубіжного досвіду для подальшого розвитку методів високоінтенсивного тренування пацієнтів, які перенесли інсульт. Методи. Аналіз наукової літератури та досвіду зарубіжних колег. Результати. Представлені фактичні дані переконують, що заходи фізичної терапії, які включають тренування з високою інтенсивністю, мають значущі переваги в підгострому періоді реабілітації для пацієнтів з інсультом порівняно зі звичайною допомогою. Підвищення інтенсивності ходьби під час навчання може впливати на величину та швидкість кроку, що приводить до збільшення та підвищеної стимуляції нервово-м'язової і кардіореспіраторної функцій. У результаті аналізу сучасної науково-методичної літератури можна стверджувати, що питання фізичної терапії пацієнтів, які перенесли інсульт, $€$ дуже актуальним. Особливо важливим є якнайшвидше надання реабілітаційних послуг з використанням найефективніших методів, які мають наукову доказовість. Одним з таких методів $€$ високоінтенсивне тренування. Ця методика відносно нова для світової спільноти й абсолютно нова для нашої країни. Отримані дані дозволяють зробити припущення про безпечність цього виду тренувань для деяких категорій пацієнтів, але варто наголосити на необхідності подальших досліджень у цьому напрямі.
\end{abstract}

Ключові слова: фізична терапія, інсульт, інтенсивне тренування.

High-intensity training as a means of physical therapy during left hemispheric hemorrhagic strokes: review of foreign experience

\section{M. Vinohradov, O. B. Lazarieva}

National University of Physical Education and Sport of Ukraine, Kyiv, Ukraine

Abstract. Stroke is a major public health issue in many countries of the world. In Ukraine, more than 111,000 new cases of stroke are registered, which are the main cause of death and disability. Objective. Study of foreign experience for further development of methods of high-intensity training of patients after a stroke. Methods. Analysis of scientific literature and experience of foreign colleagues. Results. The presented actual facts show that physical therapy measures, which include high-intensity training, have significant advantages in the subacute rehabilitation period for stroke patients compared to conventional care. Increasing the intensity of walking during training can affect the size and speed of the step, which leads to increased stimulation of neuromuscular and cardiorespiratory functions. Based on the analysis of the modern scientific and methodical literature one may state that the question of physical therapy of patients who have suffered a stroke is very actual. It is especially important to provide rehabilitation services as soon as possible using the most effective methods that have scientific evidence. One such method is high-intensity training. This technique is relatively new for the world community and completely new for our country. The obtained data allow making assumptions about the safety of this type of training for some categories of patients, but it is worth emphasizing the need for further research in this area.

Keywords: physical therapy, stroke, intensive training. 
Постановка проблеми. Інсульт $\epsilon$ найважливішою проблемою охорони здоров'я в багатьох країнах світу. Щорічно у $0,2 \%$ населення реєструють нові випадки інсульту, це приблизно 16 млн осіб, і третина з них - у країнах із середнім або низьким рівнем розвитку [29]. Третина хворих на інсульт помирає протягом наступного року, третина втрачає працездатність і лише третина хворих повністю відновлюється [18]. В Україні реєструється понад 111 тис. нових випадків інсульту, які $\epsilon$ основною причиною смертності (минулого року цей показник становив понад 41 тис.) та інвалідизації населення. Третина - у людей працездатного віку. Це близько 297 випадків на 100 тис. населення. Водночас у Європі цей показник - 200 на 100 тис. населення.

Внутрішньомозковий крововилив $\epsilon$ причиною розвитку інсульту у 10-15\% пацієнтів. Однак він залишається важливим чинником розвитку ускладнень та підвищеної смертності. Помирає близько 30 \% пацієнтів. Незважаючи на тривале лікування у відділеннях невідкладної допомоги та інтенсивної терапії, лише половина хворих, які перенесли внутрішньомозковий крововилив, виживають протягом 30 днів, а ті, хто вижив, часто мають значну інвалідність [38]. Традиційна лікувальна тактика зорієнтована на мінімізацію поширення крововиливу та зменшення обсягу ураження мозкової тканини всіма можливими засобами, включаючи і хірургічне втручання. Лікування хворих із геморагічним інсультом - складний довготривалий процес, що потребує залучення до лікування лікарів різних спеціальностей [4].

Процес реабілітації, відновлення втрачених функцій вимагає особливої наполегливості і тривалого часу. Профрілактика полягає в регулярному обстеженні, дотриманні дієтичних рекомендацій, підтриманні нормальних показників тиску, оскільки небезпека повторних апоплексій висока. До фракторів вторинного ураження мозку належать: гематоми, набряк мозку, гідроцефалія, а також системні ускладнення [22]. Згідно з наявними увленнями, на сьогодні найбільш ефективними методами фрізичної терапії після гострого порушення мозкового кровообігу є: правильне позиціонування та навчання родичів і самого пацієнта, моторний контроль (постуральний контроль та рівновага), високоінтенсивне тренування, функціональне тренування, дзеркальна терапія, терапія індуковано-обмеженого руху (СIMT), силове тренування як менеджмент спастичності, роботизована та комп'ютеризована терапія [11].

Роботу виконано згідно з планом НДР НУФВСУ на 2016-2020 рр. за темою 4.2 «Організаційні та теоретико-методичні основи фрізич- ної реабілітації осіб різних нозологічних, професійних та вікових груп» (номер держреєстрації 0116U001609).

Мета дослідження - визначити доцільність та ефективність високоінтенсивного інтервального тренування у пацієнтів після гострого порушення мозкового кровообігу за геморагічним типом у лівій півкулі.

Методи дослідження: теоретичний аналіз та узагальнення науково-методичної літератури.

Результати дослідження та їх обговорення. Інсульт - дуже багатокомпонентне захворювання, відтак способи, тривалість і результати лікування залежать від багатьох чинників, серед яких провідне місце посідають особливості паці$\epsilon$ нта (розміри та місце ураження мозку, тяжкість інсульту, вік, риси особистості і стан здоров'я до інсульту), ресурси лікарні (наявність томографої, лабораторії, ліжок для інтенсивної терапії, лікарів різних спеціальностей, зокрема кардіолога, ендокринолога, уролога, психіатра тощо) та наявність кваліфікованої міждисциплінарної команди, що має спеціальну підготовку з лікування інсульту (фахові лікарі, лікарі фрізичної та реабілітаційної медицини, медичні сестри, фрізичні терапевти та ерготерапевти, логопеди) [17].

Як свідчить світова практика, найкращі результати лікування інсульту можуть бути досягнуті при перебуванні пацієнта у спеціалізованому інсультному відділенні, яке розташоване у багатопрофрільній лікарні і дозволяє поєднати допомогу у гострому періоді захворювання з ранньою і повноцінною реабілітацією [1].

Унаслідок інсульту відбувається ушкодження головного мозку, що призводить до раптової втрати певних фрункцій, які забезпечувала його уражена частина. Ушкодження частини головного мозку може мати різноманітні наслідки: слабкість м'язів або параліч половини тіла (обличчя, рука, нога); порушення чутливості та/або сприйняття; біль на паралізованій стороні тіла; зорові порушення (втрата частини поля зору одного чи обох очей, двоїння); афразія - порушення мовлення та/або розуміння мови інших людей, а також читання, писання та називання речей; втома; порушення фрункції тазових органів (нетримання сечі або калу, затримка сечі); порушення настрою та зміна характеру (тривожність, депресія, агресія, апатія, напади безпричинного плачу або сміху); порушення пам'яті, уваги чи мислення, порушення свідомості (значна сонливість, кома) [7].

Реабілітація після інсульту - це динамічний процес, під час якого пацієнти з наслідками інсульту відновлюють свої попередні здатності (вміння, навички) чи, коли повне відновлення $€$ 
неможливим, досягають свого оптимального фрізичного, когнітивного, емоційного, соціального та комунікативного рівня фрункціонування [2].

Ранній початок реабілітації (як тільки буде досягнуто стабілізації основних вітальних фрункцій (гемодинаміки, дихання)) має позитивний вплив на відновлення функцій.

Реабілітація рекомендована всім пацієнтам після інсульту протягом перших 24-48 год._(при стабільному стані пацієнта), рівень доказовості $\mathrm{A}$, але доказова база недостатня для вибору методів відповідної терапії для найважчих пацієнтів (рівень доказовості В) [26].

Перші три місяці після інсульту $€$ найсприятливішими для відновлення втрачених фрункцій. Через шість місяців після початку інсульту люди перебувають у хронічній стадії, і мету фрізичної терапії змінюють з відновлення до підтримуючого тренування.

Основним запитом пацієнтів після інсульту, виходячи з концепції МКФ, є відновлення навичок ходьби для виконання соціальних взаємодій на рівні участі [9].

Ходьба після інсульту характеризується повільною швидкістю, поганою витривалістю та низькою ергономічністю. Серед реабілітаційних парадигм, розроблених для поліпшення рухливості у пацієнтів з інсультом, найпопулярнішим $€$ тренування на біговій доріжці, самостійно або поєднане з частковим підтриманням маси тіла (BWS). Вдосконалення швидкості ходьби такими способами значно перевершує результати, отримані звичайним тренуванням. Останнім часом було запропоновано нові парадигми тренувань, що включають режими швидкої ходьби та інтенсивного тренування [14].

Поліпшення мобільності в оточенні та громаді $є$ пріоритетом під час реабілітації інсульту, оскільки знижені фрізичні навантаження пов'язані зі зниженням здоров'я та збільшенням витрат на охорону здоров'я [7]. Конкретні пороги ємності локомоції (тобто швидкості та часу ходьби) пов'язані з більшим рівнем мобільності громади [8], який $є$ критичним з огляду на зростаючу частоту інсультів у молодому віці населення.

Для покращення опорно-рухових функцій проводиться багато втручань, які застосовуються клінічно, хоча ефрективність більшості стратегій цих втручань не визначена. Останні практичні вказівки $[11,28]$ заохочують надання тренування $з$ ходьби, пов'язаного із завданням при більш високій серцево-судинній інтенсивності для покращення як серцево-судинного здоров'я, так і функціонального рівня. Попередні контрольовані дослідження також вказують на те, що кількість та інтенсивність крокових тренуваннь пов'язані зі збільшенням швидкості ходьби та відстані [10, 13]. Однак ці дослідження проводили у пацієнтів, які перенесли інсульт не більше місяця назад, а дані з моделей показують, що попередні втручання можуть спричинити значніші покращення [5].

Незважаючи на цей потенціал, більшість спостережень свідчать, що пацієнти, які перебувають у ранньому післяінсультному періоді, отримують обмежену кількість практики у крокових діях (250-500 кроків на заняття або на день [16, $23,24])$ на низькому рівні аеробної інтенсивності, досягаючи аеробних порогів $<5$ \% усього часу занять із фрізіотерапевтом [15, 19, 21]. Хоча існує багато бар'єрів для клінічного перекладу, проте нещодавно було звернено увагу на безпеку високоінтенсивних тренувань під час стаціонарної реабілітації. Зокрема, пацієнти, які перебувають на стаціонарній реабілітації після інсульту, виконують $\approx 1500$ кроків на день і досягають більшої інтенсивності ( $\approx 40 \%$ занять) 3 істотними позитивними впливами на опорно-руховий апарат і відсутністю підвищеного ризику частоти побічних явищ та ускладнень [12].

Хоч ці висновки і багато обіцяють, вони мають певні обмеження, зокрема відсутність контрольного втручання для оцінювання ефективності інтенсивного тренування на ранніх етапах після інсульту. Стратегією оцінювання заходів втручання для визначення їх ефективності зазвичай $€$ рандомізоване контрольоване дослідження, хоча його користь може піддаватися багатьом питанням під час стаціонарної реабілітації. Для початку дані для втручання генеруються в лабораторному середовищі, і якщо результати позитивні, то їх називають заходами, заснованими на фрактичних даних. Головною метою $€$ втілення доказового втручання в клінічні установи після отримання суттєвих даних для підтримання їх ефективності. Однак під час вивчення обґрунтованих втручань протягом процесу реабілітації вони частіше надаються додатково до звичного догляду та реабілітаційного процесу.

Ефективність одного втручання не $є$ точно виявленою завдяки наданню клінічної терапії, яка найчастіше недостатньо ретельно описана та задокументована [6, 20]. Для того щоб зрозуміти вплив заходів, узгоджених у реабілітації, необхідні групи для забезпечення того, щоб заходи, засновані на фрактичних даних, запроваджувалися таким чином, щоб відповідати тому, як вони були вивчені. Це може потребувати заміни існуючих засобів, менш ефективних на практиці (тобто відмова від використання) [27], які обмежують 
надання додаткової терапії. Більшість дослідницьких парадигм не стосуються стратегій втілення для інтеграції науково-доказових заходів у клінічній практиці. Хоча такі стратегії мають важливе значення для полегшення адаптації науково-доказової практики в клінічному середовищі.

Для того щоб зменшити вплив деяких з цих проблем, дослідники використовують детально описане порівняльне дослідження ефективності з використанням історичного контролю для оцінювання переваг високоінтенсивного тренування під час стаціонарної реабілітації інсульту. Використовували квазіексперементальне проєктування, стандартизовані міри і щоденну поступову діяльність, які систематично збирали протягом 10 місяців у пацієнтів з інсультом у підгострій стадії під час стаціонарної реабілітації, тоді як фрізичні терапевти забезпечували свої типові реабілітаційні втручання. Після використання конкретного втручання $[8,25]$ терапевти пробували забезпечувати тренування з використанням високої інтенсивності під час стаціонарної реабілітації протягом наступних 11 місяців, продовжуючи стежити за результатами. Конкретні цілі зарубіжних колег полягали в тому, щоб оцінити досягнуті значення і пов'язані з ними функціональні результати під час звичайного втручання у стаціонарній реабілітації та вплив інтенсивної підготовки на функціональні результати на ранньому етапі після інсульту. Наші колеги доводили, що заходи з високою інтенсивністю мають більш значущі переваги в підгострому періоді реабілітації пацієнтів з інсультом, ніж у тих, хто отримує звичайну допомогу.

У дослідженнях зарубіжних колег ми побачили найпоширеніші методи оцінювання у фізичній терапії, які вони використовували для дослідження. І для звичайної групи, і для групи, в якій застосовували високоінтенсивне тренування, вони використовували збір результатів і щоденної діяльності учасників стаціонарної реабілітації. Лікарі мали пройти підготовку використання стандартизованої системи оцінювання за допомогою спеціальної оціночної батареї до звичайної фрази терапії. Щотижневе оцінювання включало 10-метровий тест швидкості ходьби, тест для оцінювання найбільшої швидкості ходьби, 6-хвилинний тест ходьби. Другорядні тести як під час прийому пацієнтів, так і виписки включали: шведську шкалу поступальної оцінки, кількість сидячих передач протягом 30 с, функціональну категорію здатності до пересування. Додатковими методами були системи інформування про виконану роботу самим пацієнтом: оцінювання тривоги, депресії, втоми. Щоденно для проведення високоінтенсивного крокового тренування в години бадьорості пацієнта реєструвалась активність у вигляді кількості його кроків за допомогою StepWatch, надітої на паретичну гомілку. За допомогою цього годинника була можливість розраховувати кількість кроків за 1 хв протягом сеансу фрізіотерапії [19].

Основними прогнозованими результатами наших колег виявлялися результати послідовних прогулянок, що застосовувалися до пацієнтів, які перенесли інсульт [12], і зміни кількості кроків протягом дня. Важливе значення відіграє пріоритетність практики кроків та поетапної практики, при стандартному лікуванні менше уваги приділяється моторним навичкам (баланс і функціональне переміщення). Підвищення інтенсивності кроку під час навчання може впливати на величину та швидкість кроку, що приводить до збільшення та підвищеної стимуляції нервово-м'язової і кардіореспіраторної функцій.

Особливий інтерес представляють крокові тренування у великому обсязі порівняно зі стандартним лікуванням пацієнтів на стаціонарному етапі. Спостереження в деяких закладах показали, що ступінь крокової активності, досягнутий протягом стандартного стаціонарного лікування, становив близько 250 кроків. У спробах зарубіжних колег 3 реалізації високоінтенсивного тренування крокова активність була збільшена до 1500 кроків на день [12], що різко контрастує з кількістю кроків, виконаних під час стандартного тренування.

Висновки. У результаті аналізу джерел сучасної науково-методичної літератури можна стверджувати, що питання фізичної терапії пацієнтів, які перенесли інсульт, $є$ дуже актуальним. Особливо важливим $€$ надання реабілітаційних послуг у найкоротший термін 3 використанням найефективніших методів, які мають наукову доказовість. Одним з таких методів $\epsilon$ високоінтенсивне тренування. Ця методика $\epsilon$ відносно новою для світової спільноти і абсолютно новою для нашої країни. Отримані дані дозволяють висловити припущення 3 приводу безпечності цього виду тренувань для деяких категорій пацієнтів, але варто наголосити на необхідності подальших досліджень у цьому напрямі.

Перспективи подальших досліджень передбачають звернення особливої уваги на підбір параметрів високоінтенсивного тренування для контингенту хворих у нашій країні, враховуючи рівень надання медичних послуг, умови перебування у стаціонарі, фрізіологічні та особистісні чинники пацієнтів. 


\section{Література}

1. Баннікова Р, Керестей В, Калінкін К. Перспективи застосування методу функціонального тренування при гострих порушеннях мозкового кровообігу в пізньому відновному періоді [Prospects for the application of the method of functional training in acute cerebrovascular disorders in the late recovery period].Теорія і методика фізичного виховання і спорту. 2017; (3): 60-65.

2. Кадиков АC, Шахпаронова НВ. Ранняя реабилитация больных, перенесших инсульт. Роль медикаментозной терапии [Early rehabilitation of patients after stroke.Role of medical therapy]. Нервные болезни. 2014; 1: 22-25.

3. Мицкан Б, Єдинак Г, Остапяк 3. та ін. Інсульт: різновиди, фактори ризику, фізична реабілітація [Stroke: types, risk factors, physical rehabilitation]. Фізичне виховання, спорт і культура здоров'я у сучасному суспільстві. 2012; 3 (19): 295-302.

4. Мурашко НК, Парникоза ТП, Сулик РВ и др. Реабилитация больных с инсультом: учеб.-метод. рекомендации [Rehabilitation of stroke patients]. Киев: Изд-во НМАПО. 2013.

5. Biernaskie J, Chernenko G, Corbett D. Efficacy of rehabilitative experience declines with time after focal ischemic brain injury. $\mathrm{J}$ Neurosci. 2004;24:1245-54. doi: 10.1523/JNEUROSCI.3834-03.2004

6. Duncan PW, Sullivan KJ, Behrman AL, Azen SP, Wu SS, Nadeau $\mathrm{SE}$, et al; L7EAPS Investigative Team. Body-weight-supported treadmill rehabilitation after stroke. N Engl J Med. 2011;364:2026-36. doi: 10.1056/NEJMoa1010790

7. Forster A, Young J. Incidence and consequences of falls due to stroke: a systematic inquiry. BMJ. 1995;311:83-86.

8. Graham ID, Logan J, Harrison MB, Straus SE, Tetroe J, Caswell W, et al. Lost in knowledge translation: time for a map? J Contin Educ Health Prof. 2006;26:13-24. doi: 10.1002/chp.47

9. Hebert D, Lindsay MP, McIntyre A, Kirton A, Rumney PG, Bagg S, et Al. Canadian stroke best practice recommendations: stroke rehabilitation Practice guidelines, update 2015. Int J Stroke. 2016;11:459-484. Doi: $10.1177 / 1747493016643553$

10. Hornby TG, Moore JL, Lovell L, Roth EJ. Influence of skill and exercise training parameters on locomotor recovery during stroke rehabilitation. Curr Opin Neurol. 2016;29:677-83. doi: 10.1097/WCO. 0000000000000397

11. Horbny T. George, Reisman Darcy S, Ward Irene G. et al. Clinical Practice Guideline to Improve Locomotor Function Following Chronic Stroke, Incomplete Spinal Cord Injuri, And Brain Injuri, IAPTA. 2020.

12. Hornby TG, Holleran CL, Leddy AL, Hennessy P, Leech KA, Connolly $\mathrm{M}$, et al. Feasibility of focused stepping practice during inpatient rehabilitation poststroke and potential contributions to mobility outcomes. Neurorehabil Neural Repair. 2015;29:923-932. doi: 10.1177/1545968315572390

13. Hornby TG, Straube DS, Kinnaird CR, Holleran CL, Echauz AJ, Rodriguez KS, et al. Importance of specificity, amount, and intensity of locomotor training to improve ambulatory function in patients poststroke. Top Stroke Rehabil. 2011:18:293-307. doi: 10.1310/tsr1804-293

14. Jørgensen, JR, Bech-Pedersen DT, Zeeman P, Sørensen J, Andersen LL, \& Schönberger M. Effect of intensive outpatient physical training on gait performance and cardiovascular health in people with hemiparesis after stroke. Physical therapy.2010, 90(4), 527-37.
15. Kuys S, Brauer S, Ada L. Routine physiotherapy does not induce a cardiorespiratory training effect post-stroke, regardless of walking ability. Physiother Res Int. 2006;11:219-27. doi: 10.1002/pri.344

16. Lang CE, Macdonald JR, Reisman DS, Boyd L, Jacobson Kimberley T, Schindler-lvens SM, et al. Observation of amounts of movement practice provided during stroke rehabilitation. Arch Phys Med Rehabil. 2009:90:16921698. doi: 10.1016/j.apmr.2009.04.005

17. Langhorne P, Pollock A. What are the components of effective stroke unit care? Age Ageing. 2002;31:365-71.

18. Lindsay P, Taralson C, Silver F, et al. Canadian stroke best practice recommendations: telestroke guidelines and toolkit, update 2013, www.strokebestpractices.ca (accessed 24 March 2016).

19. MacKay-Lyons MJ, Makrides L. Cardiovascular stress during a contemporary stroke rehabilitation program: is the intensity adequate to induce a training effect? Arch Phys Med Rehabil. 2002;83:1378-83. doi: 10.1053/ apmr.2002.35089

20. Pohl M, Werner C, Holzgraefe M, Kroczek G, Mehrholz J, Wingendorf I, et al. Repetitive locomotor training and physiotherapy improve walking and basic activities of daily living after stroke: a single-blind, randomized multicentre trial (DEutsche GAngtrainerStudie, DEGAS). Clin Rehabil. 2007;21:17-27. doi: 10.1177/0269215506071281

21. Prajapati SK, Mansfield A, Gage WH, Brooks D, Mcllroy WE. Cardiovascular responses associated with daily walking in subacute stroke. Stroke Res Treat. 2013;2013:612458. doi: 10.1155/ 2013/612458

22. Said CM, Galea MP, Lythgo N. People with stroke who fail an obstacle crossing task have a higher incidence of falls and utilize different gait patterns compared with people who pass the task. Phys Ther 2013; 93: 334-344.

23. Scrivener K, Sherrington C, Schurr K. Amount of exercise in the first week after stroke predicts walking speed and unassisted walking. Neurorehabil Neural Repair. 2012;26:932-38. doi: 10.1177/1545968312439628

24. Scrivener K, Sherrington C, Schurr K. Exercise dose and mobility outcome in a comprehensive stroke unit: description and prediction from a prospective cohort study. J Rehabil Med. 2012;44:824-29. doi: 10.2340/165019771028

25. Straus S, Tetroe J, Graham I. Knowledge Translation in Health Care: Moving from Evidence to Practice. West Sussex, UK: BMJ Books. 2013.

26. Stroke Unit Trialists C. Organised inpatient (stroke unit) care for stroke. Cochrane Database Syst Rev 2013;9

27. Van Bodegom-Vos L, Davidoff F, Marang-van de Mheen PJ. Implementation and de-implementation: two sides of the same coin? BMJ Qual Saf. 2017;26:495-501. doi: 10.1136/bmjqs-2016-005473

28. Winstein CJ, Stein J, Arena R, Bates B, Cherney LR, Cramer SC, et al; American Heart Association Stroke Council, Council on Cardiovascular and Stroke Nursing, Council on Clinical Cardiology, and Council on Quality of Care and Outcomes Research. Guidelines for adult stroke rehabilitation and recovery: a guideline for healthcare professionals from the American Heart Association/American Stroke Association. Stroke. 2016;47:e98-e169. doi: 10.1161/ STR.0000000000000098

29. Zhang WW, Speare S, Churilov L, Thuy M, Donnan, G Bernhardt J. Stroke rehabilitation in china: a systematic review and meta-analysis. Int $J$ Stroke 2014; 9: 494-502. 